\title{
Implementering av Suicide Status Form på akuttpsykiatrisk avdeling
}

\author{
Ved Martin Cornelius Veland og Fredrik A. Walby
}

\begin{abstract}
På akuttpsykiatrisk avdeling ved Lovisenberg Diakonale Sykehus er det gjennomført et pilotprosjekt med utprøving av et selvrapporteringsskjema for kartlegging og vurdering av selvmordsfare hos suicidale pasienter. Skjemaet som er brukt er en offisiell norsk versjon av Suicide Status Form (SSF), utviklet av David Jobes med bakgrunn i en behandlingsfilosofi hvor pasienten selv er aktivt medvirkende i vurderingen. SSF belyser psykologiske dimensjoner relatert til selvmordsfare og er bygget på et solid teoretisk rammeverk, har internasjonal anerkjennelse og kan brukes både i akutte kriser og som rutinemessig poliklinisk kartleggingsverktøy. Artikkelen gir en oversikt over innholdet i SSF, presenterer den norske oversettelsen og beskriver foreløpige erfaringer med bruk i en akuttpsykiatrisk avdeling.
\end{abstract}

\section{Innledning}

CAMS (Collaborative Assessment and Management of Suicidality) er utviklet av den amerikanske psykologen David Jobes, og støttes av 15 år med klinisk forskning (Jobes, 2006). Behandlingstilnærmingen ble utviklet for suicidale polikliniske pasienter - en pasientgruppe hvor konvensjonell behandling ofte har vært innleggelse i sengepost (Jobes, 2006). Det terapeutiske og kliniske rammeverket i CAMS-tilnærmingen har tidligere vært presentert i Suicidologi (Jobes, 2009).

Veland (2009) har beskrevet kartlegging av suicidalitet med utgangspunkt i Suicide Status Form (SSF), som er én av fire seksjoner i CAMS. Skjemaet har vært evaluert i et pilotprosjekt på Lovisenberg Diakonale Sykehus i perioden fra september 2009 til august 2010. Målet med prosjektet var å unders $\varnothing$ ke om SSF er et nyttig supplerende verkt $\varnothing y$ for kartlegging av suicidalitet på en psykiatrisk akuttavdeling. Pilotprosjektet startet som et resultat av at miljøpersonalet opplevde å mangle en standardisert og systematisk prosedyre for kartlegging av selvmordsfare. SSF ble valgt på bakgrunn av bakenforliggende behandlingsfilosofi og brukervennlighet, da denne syntes å passe godt inn i behandlingssystemet på akuttpsykiatrisk avdeling (AKU). Som en del av prosjektet er SSF oversatt til norsk, og det er gjort en tilbakeoversettelse til engelsk. Tilbakeoversettelsen samsvarte godt med den engelske originalen, og kun mindre språklige revisjoner ble gjort som følge av denne. Den norske versjonen er utviklet med tillatelse fra opphavsmannen David Jobes, og publiseres sammen med denne artikkelen.
Hensikten med denne artikkelen er å gi en oversikt over bakgrunnen for utviklingen av SSF, presentere den norske oversettelsen og beskrive forel $\varnothing$ pige erfaringer med utpr $\varnothing$ vingen.

\section{Suicide Status Form (SSF)}

Første del av SSF består av spørsmål som omhandler fem sentrale suicidologiske begreper med omfattende teoretisk relevans og empirisk st $\varnothing$ tte: psykisk smerte, stress, indre uro (Shneidman, 1993), håpløshet (Beck, 1985) og selvhat (Baumeister, 1990). Ifølge Jobes (2006) er dette viktige områder å kartlegge fordi de kan være forbundet med $\varnothing \mathrm{kt}$ risiko for selvmord. Pasientene scorer hver og en av dimensjonene kvantitativt på en skala fra 1 til 5. Etter hver kvantifisering bes pasienten kort beskrive kvalitativt hva tallverdien representerer. Informasjonen som kommer frem her vil bidra til at den gitte tallverdien gir mer klinisk relevans for den eller de som behandler pasienten. Tallverdien sier noe om lidelsestrykket, det beskrivende svaret sier noe om hva lidelsestrykket innebærer.

I skjemaets andre del kartlegges pasientens selvmordsfare i form av spørsmål som direkte omhandler pasientens egen vurdering av suicidale forestillinger og relaterte forhold. Denne delen vektlegger i hovedtrekk forhold som kan forh $\varnothing$ ye faren for selvmord, samt identifiserer beskyttende faktorer. Som en del av denne vurderingen blir det kartlagt om suicidaliteten er forankret i tanker og følelser knyttet til seg selv eller i relasjonelle problemer. Pasienten bruker ovennevnte skala til å score i hvilken grad de $\varnothing$ nsker å leve eller $\mathrm{d} \phi$. En pasient som scorer høyest på ønske om å dø vil kunne formidle at "dersom tilstanden min ikke fär en forandring $i$ riktig retning, vil selumord være et middel for å oppnå denne forandringen". Selv om pasienten angir et sterkt $\varnothing$ nske om å $d \varnothing$, vil pasienten samtidig kunne ha et $\varnothing$ nske om å leve, hvorav ambivalens kan komme til utrykk. Pasienten oppfordres til å skrive ned argumenter for å leve og argumenter for å ville dø. Ifølge Jobes (2006) kan man på denne måten få kartlagt viktig informasjon slik som pasientens tilgjengelige relasjonelle ressurser og iboende beskyttende verdier.

\section{Prosedyre for bruk av SSF på} akuttavdelingens inntakspost

AKU tar imot pasienter som trenger $\varnothing y e b l i k k e l i g$ hjelp hele døgnet. Pasientene er hovedsakelig henvist fra Tøyen DPS, Lovisenberg DPS, Oslo kommunale legevakt eller fastlege. Ved innkomst blir pasienten tatt imot av vakthavende lege, hvor blant annet aktuell suicidalitet vurderes i tråd med Nasjonale retningslinjer for selvmordsforebygging i psykisk helsevern (2008). Denne selvmordsrisikovurderingen og bruk av SSF er to separate prosedyrer, hvor SSF er ment som et supplement.

I pilotprosjektet ble SSF benyttet overfor pasienter der selvmordsproblematikk var en del av innleggelsesgrunnlaget eller der selvmordsproblematikk fremkom i innkomstsamtalen. Overfor pasienter som var innlagt til tvungent vern, psykotiske pasienter og pasienter som var synlig ruspåvirket, ble SSF ikke benyttet. SFF ble altså brukt overfor pasienter som hadde det til felles at de hadde et eksplisitt eller implisitt $\varnothing$ nske om å motta hjelp. Hvilke pasienter som skulle gjennomgå 


\section{$\underline{\text { SSF }}$}

Pasient:

Kontakt:

Dato:

Tid:

Score og fyll ut hvert punkt i forhold til hvordan du har det nå.

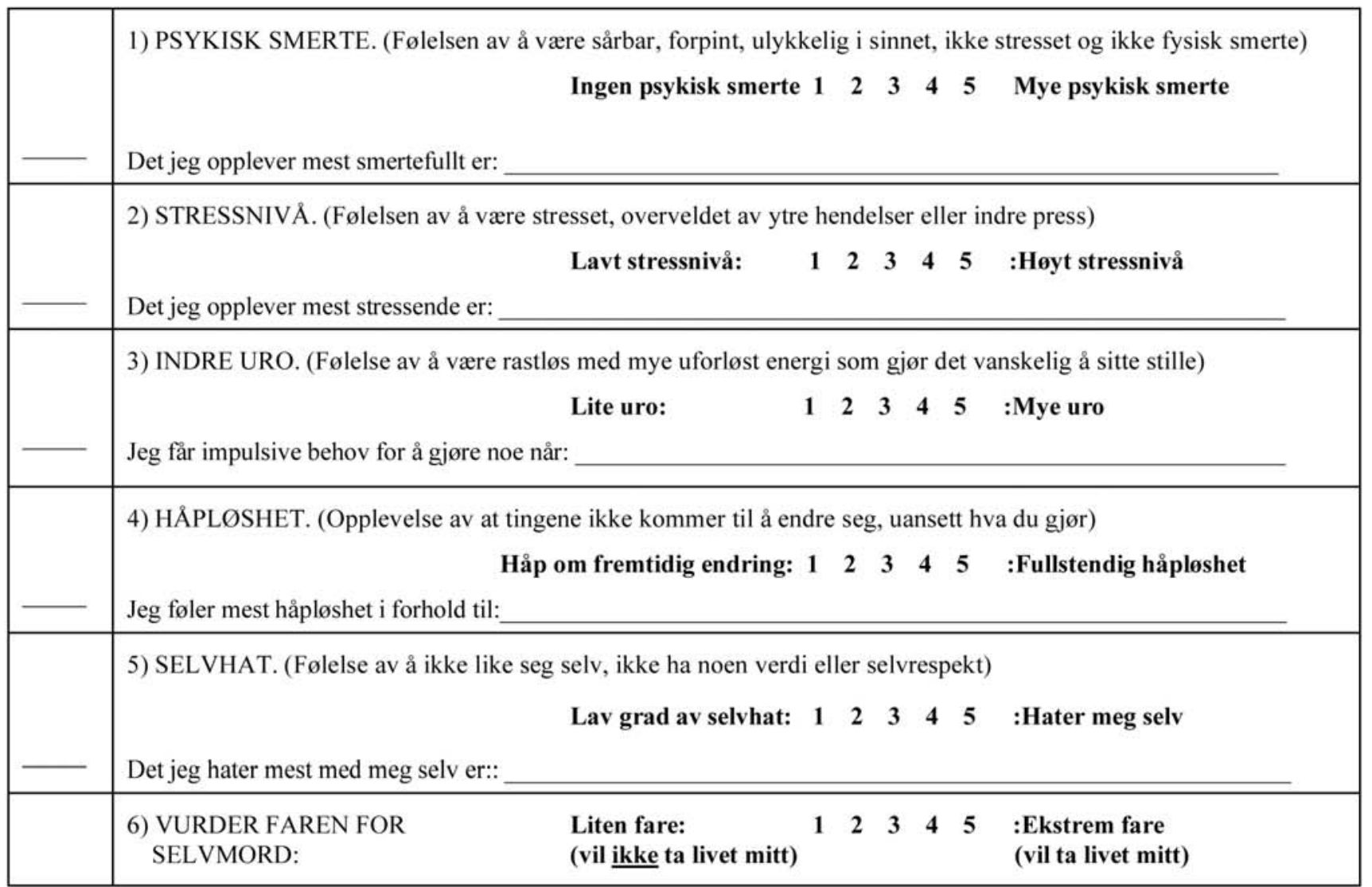

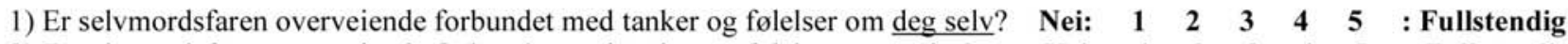

2) Er selvmordsfaren overveiende forbundet med tanker og følelser om andre? $\quad \begin{array}{llllllll}\text { Nei: } & \mathbf{1} & \mathbf{2} & \mathbf{3} & \mathbf{4} & \mathbf{5} & \text { : Fullstendig }\end{array}$

\begin{tabular}{|l|l|l|l|}
\hline & GRUNNER FOR § DØ & & \\
\hline & & & \\
\hline & & & \\
\hline & & & \\
\hline & & & \\
\hline & & & \\
\hline
\end{tabular}

Jeg ønsker å dø:

Jeg ønsker å leve:
Ikke i det hele tatt $1 \quad 2 \quad 3 \quad 3 \quad 4 \quad 5 \quad$ I meget stor grad

Ikke i det hele tatt $1 \quad 2 \quad 3 \quad 4 \quad 5$ I meget stor grad

Jeg har tanker om å avslutte livet mitt: Aldri $\quad$ Sjeldent $\quad$ Noen ganger $\quad$ Ofte Hele tiden

Den ene tingen som kunne hjelpe meg til ikke lenger føle meg selvmordstruet ville være: 
SSF ble vurdert av sykepleier, lege eller psykiater. Skjemaet ble administrert av sykepleiere i posten, som satt sammen med pasienten, veiledet og motiverte for utfyllingen. Hvilke spørsmål som ble besvart, hvor lang tid utfyllingen tok og hvor mye pasienten $\varnothing$ nsket å formidle, var opp til pasienten. Prosedyren var slik at skjema skulle brukes så raskt som mulig etter innleggelsen, dog med forutsetning om at pasienten hadde fått tid til å samle seg noe. Pasienter som ble innlagt sent på kvelden eller om natten gjennomgikk skjema påfølgende dag. Pasienten fylte ut SSF i papirformat. Deretter overførte sykepleier resultatene til en utarbeidet elektronisk versjon i avdelingens databaserte journalsystem for å gjøre informasjonen fra SSF tilgjengelig for alt involvert behandlingspersonell.

\section{Klinisk nytte av innhentet informasjon}

Etter at SSF er gjennomført, kan behandlingspersonalet oppsummere sammen med pasienten og prøve å finne realistiske behandlingsmål. En pasient som eksempelvis angir tallverdien 5 på stress, og videre skriver at det han opplever som mest stressende er "... de uåpnede regningene som ligger hjemme”, vil i de fleste behandlingssystemer kunne tilbys et møte med sosionom. Sosionomen kan bidra både med $\varnothing$ konomisk rådgivning og eventuelt etablering av nedbetalingsplan. I mange tilfeller vil suicidalitet være utløst av belastninger i den aktuelle livssituasjonen. Det kan derfor tenkes at en reduksjon av disse belastningene kan dempe suicidale impulser.

\section{Foreløpige erfaringer fra prosjektet}

Sykepleierne som har gjennomgått SSF med pasientene har gradvis blitt tryggere på bruken av skjemaet. Etter hvert som den bakenforliggende filosofien og brukermanualen til CAMS har blitt kjent blant avdelingens personell, har potensialet til SSF som redskap i behandlingen blitt mer tydelig. Erfaringen med bruk av SSF på akuttpsykiatrisk avdeling tyder på at mye av nytteverdien er avhengig av pasientens meddelsomhet. Pasienter som legges inn og er aktivt hjelps $\varnothing$ kende vil ofte være meddelsomme, og et godt samarbeid kan etableres gjennom en behandlingsorientert dialog mellom sykepleier og pasient. Opplysninger som registreres via en slik samtale kan også være nyttige for andre som er involvert i behandlingen.

\section{Utfordrende å etablere samarbeid}

Pasienter som helst vil være alene og som ikke ønsker å snakke, kan by på utfordringer for sykepleierne når det gjelder å kartlegge aktuell selvmordsrisiko. Alvorlig deprimerte pasienter kan fremstå som avvisende og lite interessert $\mathrm{i}$ behandlingen, og som kartlegger må man i slike tilfeller være aktiv, spørrende og st $\varnothing$ ttende i gjennomgangen av SSF. Hvis sykepleier er passiv, kan det hende at pasienten krysser av uten å reflektere over svaret, for å bli ferdig så fort som mulig. Erfaringsmessig er det ofte lettest for pasienten å krysse av for en tallverdi, men mer utfordrende å beskrive hva som ligger bak det tallmessige uttrykket. Men et skjema som bare inneholder kvantitative data gir jo behandlerne mindre informasjon enn et skjema som også inneholder kvalitative beskrivelser. Som kartlegger vil man være opptatt av å hjelpe pasienten til å få frem klinisk relevante opplysninger som kan benyttes direkte i behandlingen. Hos mange pasienter har vi opplevd at bruk av SSF kan fremme nye og mer aktive måter å reflektere rundt selvmordstanker og impulser på. En endring i behandlingen av suicidale pasienter på AKU som følge av pilotprosjektet er at sykepleierne på inntaksposten har fătt en mer konkret og aktiv rolle i møte med suicidalitet ved å administrere SSF. Det ser også ut til at suicidale pasienter overveiende opplever SSF som nyttig. Foreløpig ser det ut til at rutinemessig bruk av SSF $\varnothing$ ker omfanget av klinisk relevant informasjon til bruk i vurdering og behandling av pasienter med selvmordsfare i en akuttpsykiatrisk sengepost. Fremover skal bruken av SSF evalueres videre i forhold til nytteverdi og brukervennlighet. Blant annet vil innsamlede data fra 106 pasienter som har gjennomgått SSF bli analysert.
Dersom du ønsker å få tilsendt den norske oversettelsen kan du sende en mail til martin.veland@lds.no.

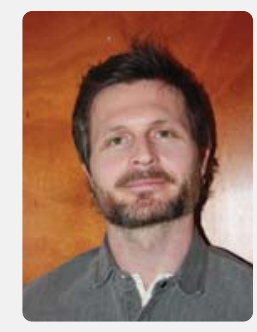

Martin C. Veland er spesialsykepleier ved akuttpsykiatrisk avdeling på Lovisenberg Diakonale Sykehus. Ved siden av stillingen på Lovisenberg, er han mastergradstudent ved $\mathrm{UiO}$ "Psykososialt arbeid" med studieretning Selvmord.

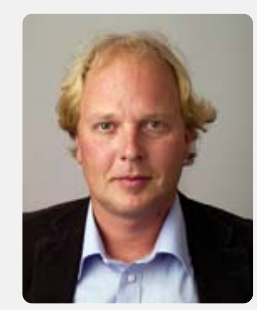

Fredrik A. Walby er sjefpsykolog ved Psykiatrisk avdeling, Diakonhjemmet sykehus og forsker ved NSSF. Han har vært sentral i arbeidet med utarbeidelse og implementering av kliniske retningslinjer for selvmordsforebygging i psykisk helsevern, har undervist og publisert forskningsarbeider innen klinisk suicidologi. Walby er også teamleder for et DBT-team.

\section{Referanser}

Baumeister, R.F. (1990). Suicide as escape from self. Psychological Review, 97, 90-113

Beck, A.T. (1985). Hopelessness and eventual suicide: A 10 year prospectivestudy of patients hospitalized with suidical ideation. American Journal of Psychiatry, 142, 559-563

Jobes, D. (2006) Managing Suicidal Risk, A Collaborative Approach. The Guilford Press

Jobes, D. (2009) The CAMS Approach to Suicide Risk. Suicidologi Nr. 1 (3-7)

Shneidman, E. (1993) Suicide as psychache; a clinical approach to self-destuctive behavior. Northvale, NJ: Aronson

Sosial- og helsedirektoratet (2008). Nasjonale retningslinjer for forebygging av selvmord $i$ psykisk helsevern (IS-1511). Oslo: Sosial- og helsedirektoratet.

Veland, M.C. (2009) Selvmord Status Skjema: - En mulighet for pasienter å utrede sin suicidale tilstand? Prosjektoppgave, Videreutdanning i selvmordsforebyggende arbeid, UIO. 